\title{
Subcellular Targeting, Experimental
}

National Cancer Institute

\section{Source}

National Cancer Institute. Subcellular Targeting, Experimental. NCI Thesaurus. Code C19319.

A molecular biology research technique whereby a protein is eng ineered to contain signals which will target it to a specific subcellular location. 